\title{
PENGARUH LATIHAN SENAM OTAK DAN ART THERAPY TERHADAP FUNGSI KOGNITIF LANSIA DENGAN DEMENSIA DI PSTW YOGYAKARTA UNIT BUDI LUHUR DAN ABIYOSO
}

\author{
Dewi Murdiyanti Prihatin Putri ${ }^{*}$, Prof. Elly Nurrachmah, DNSc. ${ }^{2}$, Dewi Gayatri, SKp.M.Kes ${ }^{3}$ \\ 1. Fakultas Ilmu Keperawatan Universitas Indonesia Depok 16424 Indonesia \\ 2. Akademi Keperawatan Yayasan Keperawatan Yogyakarta 55182 Indonesia \\ *E-mail : dewimpp_09@yahoo.co.id
}

\begin{abstract}
Abstrak
Sebagian besar lansia mengalami demensia dan penatalaksanaannya dapat dilakukan dengan cara farmakologi dan non farmakologi. Penelitian ini bertujuan untuk mengetahui pengaruh latihan senam otak dan art therapy terhadap fungsi kognitif lansia dengan demensia di PSTW Yogyakarta Unit Budi Luhur dan Unit Abiyoso Yogyakarta. Rancangan penelitian ini adalah Quasy Experimental Pre-Post Control Goup Design. Responden dalam penelitian ini berjumlah 82 orang yang terbagi menjadi kelompok kontrol dan kelompok intervensi. Pengukuran fungsi kognitif lansia dengan demensia menggunakan Mini-Mental State Examination (MMSE). Pada kedua kelompok terjadi peningkatan fungsi kognitif namun pada kelompok intervensi lebih tinggi dibandingkan kelompok kontrol. Rekomendasi penelitian ini adalah penerapan latihan senam otak dan art therapy dapat dilakukan pada lansia.
\end{abstract}

Kata kunci : Latihan senam otak, art therapy, fungsi kognitif, lansia, demensia

\begin{abstract}
Most of elderly suffer from dementia.The management of dementia can be done through pharmacology and non pharmacology ways. This research was to identify the Influence of Brain Gym Exercise and Art Therapy on the Elderly's cognitive function with Dementia at PSTW Yogyakarta Unit Budi Luhur and Abiyoso Unit Yogyakarta. This research used a Quasy Experimental Pre-Post Control Group Design. The total of respondents in this research were 82 people who divided in to a control group and intervention group. The measurement of the Elderly's cognitive function was conducted on every Sunday using Mini-Mental State Examination (MMSE). Findings of the research was demonstrated that there is an improvement in the cognitive function for both group, even though, the intervention group is higher than the control group. Recommendation of this research is to implement the Brain Gym Exercise and Art Therapy for elderly not only for those who experience dementia but also for other elderly brain condition.
\end{abstract}

Key words: Brain gym exercise, art therapy, cognitive function, elderly, dementia.

\section{PENDAHULUAN}

Prosentase penduduk lansia yang telah mencapai angka di atas tujuh persen menunjukkan bahwa negara Indonesia sudah mulai masuk ke kelompok negara dengan struktur tua (Ageing Structure Population). Struktur penduduk yang menua tersebut merupakan salah satu indikator keberhasilan pencapaian pembangunan nasional, khususnya sebagai cerminan dari semakin panjangnya rata-rata usia penduduk Indonesia. $^{2}$
Berdasarkan hasil dari Sensus Penduduk tahun 2010 secara umum jumlah penduduk lansia di Indonesia sebanyak 18,04 juta orang atau 7,59 persen dari keseluruhan penduduk. Jumlah penduduk lansia perempuan sebanyak 9,75 juta orang lebih banyak dari jumlah penduduk lansia laki-laki sebesar 8,29 juta orang. Jika dilihat menurut kelompok umur, jumlah lansia terbagi menjadi lansia muda (60 - 69 tahun) sebanyak 10,75 juta orang, lansia menengah (70 - 79 tahun) sebanyak 5,43 juta orang dan lansia tua (80 tahun ke atas) sebanyak 1,86 juta orang. ${ }^{17}$ 
Diperkirakan jumlah penduduk lansia di Indonesia akan terus bertambah sekitar 450.000 jiwa pertahun. Padahal jumlah penduduk di Indonesia selama kurun waktu yang sama hanya meningkat sekitar dua kali lipat. $^{3}$

Laporan Departemen Kesehatan RI tahun 1998 mengatakan bahwa peningkatan angka kejadian demensia berbanding lurus dengan meningkatnya umur harapan hidup suatu populasi. Kira-kira 5\% usia lanjut pada rentang usia 65 - 70 tahun menderita demensia menigkat dua kali lipat setiap 5 tahun mencapai lebih $45 \%$ pada usia diatas 85 tahun. Demensia adalah kumpulan gejala yang ditandai dengan gangguan kognitif dan memori yang dapat mempengaruhi aktifitas sehari-hari. Penderita Alzheimer mengalami gangguan memori dan proses berpikir sehingga mempengaruhi individu pada kemampuan membuat keputusan. $^{7}$

Penurunan fungsi kognitif yang terjadi pada lansia dengan demensia seringkali mempengaruhi aktivitas sehari-hari dan interaksi sosial lansia. Kondisi ini juga akan berpengaruh terhadap kualitas hidup lansia. Intervensi-intervensi yang menstimulasi fungsi kognitif sangat diperlukan untuk meningkatkan kualitas hidup lansia dengan demensia. Penatalaksanaan demensia dapat dilakukan dengan cara farmakologi dan non farmakologi. Intervensi farmakologi yaitu dengan diberikan obat-obatan yang dapat memperbaiki fungsi kognitif dan intervensi non farmakologi meliputi intervensi-intervensi yang tercakup ke dalam Cognitive Rehabilitation Therapy (CRT). Salah satu dari intervensi CRT adalah terapi alternatif yang antara lain terapi seni (Art Therapy) dan terapi aktifitas seperti latihan senam otak.20

Upaya untuk mempertahankan kemampuan memori dan kognitif agar tidak menurun belum banyak dilakukan penelitian. Sampai saat ini belum ada penelitian tentang pengaruh latihan senam otak dan art therapy terhadap fungsi kognitif di Yogyakarta maupun di Indonesia.

Tujuan umum penelitian ini adalah untuk mengetahui pengaruh latihan senam otak dan art therapy terhadap fungsi kognitif pada lansia dengan demensia. Tujuan khusus meliputi diketahuinya:

1. Karakteristik lansia dengan demensia,

2. Fungsi kognitif pada lansia dengan demensia sebelum diberikan intervensi,

3. Perbedaan fungsi kognitif pada lansia dengan demensia sebelum dan sesudah dilakukan latihan senam otak dan art therapy pada kelompok intervensi serta sebelum dan sesudah dilakukan senam lansia pada kelompok kontrol,
4. Perbedaan fungsi kognitif antara kelompok intervensi dan kelompok kontrol sesudah dilakukan intervensi baik latihan senam otak dan art therapy maupun senam lansia

5. Selisih perbedaan fungsi kognitif antara kelompok intervensi dan kelompok kontrol

\section{METODE PENELITIAN}

Penelitian ini menggunakan rancangan Quasy Experiment Pre - Post Control Group Design, dimana pengelompokan anggota sampel pada kelompok intervensi dan kelompok kontrol dilakukan secara random atau acak sederhana. Intervensi yang diberikan berupa latihan senam otak dan art therapy pada kelompok intervensi dan senam lansia pada kelompok kontrol. Analisis data dilakukan secara univariat dan bivariat yaitu dengan frekuensi chi-square, dan uji tindependent dan $\mathrm{t}$ dependent.

Instrumen penelitian yang digunakan adalah MiniMental State Examination yang terdiri dari enam bagian, yaitu Orientasi, Registrasi, Perhatian dan Hitungan, Daya ingat, Bahasa, Motorik Dasar dengan skor maksimal seluruhnya adalah 30 (tiga puluh). Pengukuran fungsi kognitif lansia dilakukan sebelum intervensi, sesudah intervensi dan setiap minggu selama 4 (empat) minggu. Interpretasi pengukuran MMSE adalah jika skor 27 - 30 poin berarti normal atau tidak ada gangguan fungsi kognitif (normal cognitive function), gangguan kognitif ringan (mild cognitive function) jika skor yang diperoleh $21-26$ poin, gangguan kognitif sedang (moderate cognitive function) dengan skor $11-20$ poin, dan gangguan kognitif berat (severe cognitive function) dengan skor 0 -10 poin. $^{4}$

\section{POPULASI DAN SAMPEL}

Populasi dalam penelitian ini adalah seluruh lansia yang tinggal di Panti Sosial Tresna Wreda sebanyak 214 orang. Tehnik pengambilan sampel menggunakan simple random sampling. Jumlah sampel sebanyak 82 terdiri dari 41 kelompok intervensi dan 41 kelompok kontrol dengan kriteria lansia berusia 60 - 90 tahun, mengalami derajat demensia dari sangat ringan sampai dengan ringan, tidak memiliki riwayat mengkonsumsi alkohol dan tidak mengalami penurunan kesadaran.

\section{HASIL DAN PEMBAHASAN}

\section{A. Karakteristik responden}

Seluruh karakteristik responden yang terdiri dari umur, jenis kelamin, riwayat pendidikan, riwayat pekerjaan dan dukungan keluarga memiliki bentuk katagorik, sehingga dideskripsikan ke dalam tabel distribusi frekuensi. Tabel distribusi frekuensi karakteristik responden kelompok intervensi dan kelompok kontrol ini dirangkum dalam satu tabel sehingga dapat dilihat perbandingannya. 
Tabel 1

Distribusi Frekuensi Lansia dengan Demensia Menurut Karakteristik Umur, Jenis Kelamin, Pendidikan, Riwayat Pekerjaan, dan Dukungan Keluarga

Tahun 2012

\begin{tabular}{|c|c|c|c|c|c|c|c|}
\hline \multirow[t]{2}{*}{ No } & \multirow[t]{2}{*}{ Variabel } & \multicolumn{2}{|c|}{$\begin{array}{l}\text { Kelompok Intervensi } \\
\qquad(\mathrm{n}=41)\end{array}$} & \multicolumn{2}{|c|}{$\begin{array}{l}\text { Kelompok Kontrol } \\
\qquad(\mathrm{n}=41)\end{array}$} & \multicolumn{2}{|c|}{$\begin{array}{l}\text { Jumlah } \\
(\mathrm{n}=82)\end{array}$} \\
\hline & & $f(x)$ & $\%$ & $f(x)$ & $\%$ & $f(x)$ & $\%$ \\
\hline \multirow[t]{4}{*}{1} & Umur & & & & & & \\
\hline & $60-69$ thn & 12 & 29,3 & 13 & 31,7 & 25 & 30,5 \\
\hline & $70-79$ thn & 15 & 36,6 & 24 & 58,5 & 39 & 47,6 \\
\hline & $80-90$ thn & 14 & 34,1 & 4 & 9,8 & 18 & 22,0 \\
\hline \multirow[t]{3}{*}{2} & Jenis Kelamin & & & & & & \\
\hline & Perempuan & 27 & 65,9 & 36 & 87,8 & 63 & 76,8 \\
\hline & Laki-laki & 14 & 34,1 & 5 & 12,2 & 19 & 23,2 \\
\hline \multirow[t]{6}{*}{3} & Pendidikan & & & & & & \\
\hline & Tdk Sekolah & 19 & 46,3 & 20 & 48,8 & 39 & 47,6 \\
\hline & $\mathrm{SD}$ & 9 & 22,0 & 10 & 24,4 & 19 & 23,2 \\
\hline & SMP & 4 & 9,8 & 6 & 14,6 & 10 & 12,2 \\
\hline & SMA & 6 & 14,6 & 3 & 7,3 & 9 & 11,0 \\
\hline & $\mathrm{PT}$ & 3 & 7,3 & 2 & 4,9 & 5 & 6,1 \\
\hline \multirow[t]{8}{*}{4} & Riwayat Pekerjaan & & & & & & \\
\hline & Tdk Bekerja & 6 & 14,6 & 5 & 12,2 & 11 & 13,4 \\
\hline & PRT & 8 & 19,5 & 9 & 21,95 & 17 & 20,7 \\
\hline & Buruh & 15 & 36,6 & 9 & 21,95 & 24 & 29,3 \\
\hline & Guru/PNS & 2 & 4,9 & 3 & 7,3 & 5 & 6,1 \\
\hline & Pedagang/wiraswasta & 5 & 12,2 & 10 & 24,4 & 15 & 18,3 \\
\hline & Petani & 3 & 7,3 & 2 & 4,9 & 5 & 6,1 \\
\hline & Swasta & 2 & 4,9 & 3 & 7,3 & 5 & 6,1 \\
\hline \multirow[t]{4}{*}{5} & Dukungan Keluarga & & & & & & \\
\hline & Tidak Pernah & 21 & 51,2 & 13 & 31,7 & 34 & 41,5 \\
\hline & Jarang $(1-2 \mathrm{x} /$ th $)$ & 8 & 19,5 & 12 & 29,3 & 20 & 24,4 \\
\hline & Sering $(6-12 x /$ th $)$ & 12 & 29,3 & 16 & 39,0 & 28 & 34,1 \\
\hline
\end{tabular}

Sebagian besar berumur antara 70 - 79 tahun yang masuk dalam kategori lansia pertengahan yaitu sebanyak $47,6 \%$ dari total responden 82 orang, hal ini diperkuat pula dengan hasil sensus penduduk (2010) menunjukkan bahwa umur harapan hidup lansia di Daerah Istimewa Yogyakarta (DIY) meningkat mencapai rata-rata 74 tahun. Hal ini tentunya sangat dipengaruhi oleh beberapa faktor yang berasal dari dirinya atau yang berasal dari lingkungan sosialnya, dan salah satu faktor yang sangat menentukan adalah lansia saat ini mampu menjalani pola hidup sehat. ${ }^{18}$

Diketahui juga bahwa sebagian besar responden berjenis kelamin perempuan $(76,8 \%)$, Penelitian ini juga diperkuat oleh suatu penelitian yang dilakukan pada lansia di Panti dengan metode cross sectional dan jumlah sampel 70 lansia dari data karakteristik responden yaitu jenis kelamin didapatkan data sebagian besar responden berjenis kelamin perempuan sebanyak
$55,7 \%$. Hal ini menujukkan bahwa lansia yang tinggal di panti sebagian besar berjenis kelamin perempuan. ${ }^{11}$ Hal ini didukung pula dari hasil sensus penduduk tahun 2010 bahwa umur harapan hidup perempuan lebih tinggi daripada laki-laki ( pada laki-laki 73 tahun dan perempuan 76 tahun). ${ }^{18}$ Suatu penelitian yang dilakukan dengan metode survei tentang profil penduduk lanjut usia di Indonesia dengan jumlah sampel 18.476 orang lansia menunjukkan bahwa sebagian besar lansia berjenis kelamin perempuan yaitu sebesar $70 \%$ dari jumlah sampel. Hal ini disebabkan karena panjang angka harapan hidup lanjut usia perempuan sesuai dengan angka harapan hidup waktu lahir diman perempuan memiliki angka harapan hidup waktu lahir lebih tinggi dari laki-laki. Kondisi ini dipengaruhi oleh pengaruh hormonal pada wanita usia produktif dimana hormon estrogen mempunyai peranan sebagai pelindung yang menyebabkan angka harapan hidup waktu lahir untuk perempuan lebih tinggi dari 
pada laki-laki. Sedangkan pada laki-laki peranan estrogen sangat sedikit, disamping itu laki-laki memiliki beban kerja fisik yang lebih berat serta ditambah pula dengan perilaku merokok dan makan yang kurang berimbang pada laki-laki. ${ }^{16}$

Sebagian besar responden tidak bersekolah sebanyak $47,6 \%$, Hasil ini diperkuat dengan penelitian lain yang metode quasy-experiment menggambarkan jumlah lansia yang tidak bersekolah sebesar $40,74 \%$ hal ini disebabkan karena kesadaran lansia dahulu terhadap pendidikan masih rendah disertai pula keterbatasan sarana dan prasarana pendidikan saat itu mengakibatkan banyak lansia yang memilih untuk tidak sekolah. Sebagian besar lansia pernah bekerja sebesar $86,6 \%{ }^{15}$ Hal ini didukung oleh hasil wawancara yang dilakukan kepada 10 lansia di PSTW Yogyakarta didapatkan data bahwa semua lansia berpikiran untuk mempertahankan hidup dan mencukupi kebutuhan diri dan keluarga harus bekerja walaupun dengan pendidikan yang rendah atau tidak bersekolah sehingga pekerjaan yang dilakukan sebagian besar menjadi pembantu rumah tangga dan buruh.

Terdapat $41,5 \%$ responden tidak pernah mendapat kunjungan keluarga, Sebagian besar lansia dengan demensia tidak mendapatkan dukungan keluarga karena sebagian dari lansia yang tinggal di panti tidak menikah atau sebatang kara dan tidak memiliki keluarga bahkan sebagian lansia yang terlantar yang diserahkan oleh Dinas Sosial Propinsi DIY. Hal ini didukung oleh suatu penelitian yang mengatakan bahwa tidak semua lansia bisa menikmati masa senjanya dalam kehangatan keluarga karena lansia harus berada jauh dari anak dan kerabatnya di panti wreda. Panti wreda merupakan tempat hunian lansia yang memiliki masalah baik masalah psikologi dan penurunan fisik yang dapat mengakibatkan depresi sehingga lansia menjadi merasa tidak bahagia di masa senjanya. ${ }^{8}$

\section{B. Perbedaan fungsi kognitif pada kelompok kontrol dan kelompok intervensi}

Fungsi kognitif pada kelompok kontrol maupun kelompok intervensi sebelum dilakukan intervensi adalah sama atau seimbang. Hal ini dibuktikan dengan hasil pengujian kesetaraan atau uji homogenitas fungsi kognitif sebelum intervensi menunjukkan bahwa kedua kelompok memiliki derajat kesetaraan yang sama dengan nilai $\mathrm{p}=0,93(\mathrm{p}$ value $>\alpha=0,05)$ atau dengan kata lain kedua kelompok tersebut adalah homogen. Data ini muncul disebabkan karena dua panti tempat lansia tinggal berada dalam satu atap atau satu pengelolaan dengan nama PSTW Yogyakarta milik pemerintah yang dipimpin oleh seorang kepala panti. Kedua panti tersebut memiliki kegiatan yang sama setiap harinya. Fasilitas yang diberikan di kedua panti tersebut juga sama seperti wisma yang ditempati lansia berisikan lansia sejumlah 6 (enam) sampai dengan 12 (duabelas) lansia setiap wismanya dengan masingmasing kamar berisi 2 (dua) orang lansia. Pemberian makanan dan snack yang disajikan dengan frekuensi pemberian yang sama setiap hari.

Pada kelompok intervensi lansia dengan demensia diberikan latihan senam otak sebanyak $3 x$ seminggu dan art therapy sebanyak $2 \mathrm{x}$ seminggu selama 4 (empat) minggu. Setelah diberikan intervensi terdapat peningkatan fungsi kognitif yang bermakna pada kelompok intervensi setelah dilakukan senam otak dan art therapy. Penelitian lain yang sesuai dengan penelitian ini menyatakan bahwa setelah dilakukan latihan senam otak sebanyak $3 x$ seminggu selama 2 bulan terdapat peningkatan memori jangka pendek pada anak dengan ekonomi rendah. ${ }^{14}$

Seperti yang diungkapkan penemu senam otak pertama kali yaitu Paul E. Dennison, Ph.D yang mengatakan bahwa gerakan senam otak akan menstimulasi aliran informasi pada jaringan saraf, memulihkan kemampuan dalam proses belajar dan fungsi-fungsi yang lain. Ditambah lagi gerakan menyilang pada latihan senam otak merupakan kunci keberhasilan untuk menginterasikan fungsi hemisfer otak kanan dan kiri. ${ }^{5}$ Disamping itu menggambar juga merupakan aktivitas yang meningkatkan koordinasi tangan dan gerakan mata dan bagian lain dari tubuh serta peningkatan gerakan tubuh dan aktivitas yang bersamaan antara hemisfer kanan dan kiri dari otak. ${ }^{9}$ Penelitian yang dilakukan dengan metode studi kasus di Sydney Australia memberikan intervensi art therapy secara berkelompok kepada lansia berusia 82 tahun sebanyak 6 kali pertemuan, dan setiap pertemuan kurang lebih selama satu sampai dua jam. Intervensi art therapy dapat dilakukan oleh terapis seni maupun oleh perawat spesialis. Art Therapy dapat dilakukan dengan beberapa cara diantaranya dengan memberikan suatu bahan yang berwarna dan meminta lansia untuk membuat suatu bentuk misalnya segitiga, bujursangkar ataupun lingkaran. Dapat pula dengan cara lansia diminta untuk mewarnai suatu sketsa gambar atau lansia menggambar kemudian diwarnai. ${ }^{12}$ Latihan senam otak dan art therapy yang dilakukan secara bersamaan dapat memberikan hasil atau meningkatkan fungsi kognitif lansia dengan demensia.

Pada kelompok kontrol setelah diberikan senam lansia setiap hari selama 4 (empat) minggu ditemukan adanya peningkatan fungsi kognitif yang bermakna Peningkatan kemampuan kognitif tersebut juga didukung oleh pernyataan bahwa penurunan intensitas dan durasi aktifitas akan mempercepat proses penurunan fungsi kognitif. Untuk mencegah terjadinya penurunan fungsi kognitif maka diperlukan aktifitas fisik secara rutin dan teratur. ${ }^{6}$ 
Tabel 2

Analisis Pengaruh Latihan Senam Otak dan Art Therapy Terhadap Fungsi Kognitif Lansia dengan Demensia Tahun 2012

\begin{tabular}{lcccccccc}
\hline \multicolumn{1}{c}{ Kelompok } & Mean & $\mathrm{N}$ & $\mathrm{SD}$ & $\mathrm{SE}$ & $\begin{array}{c}\text { MDiff } \\
(95 \% \mathrm{CI})\end{array}$ & $\mathrm{t}$ & $\mathrm{df}$ & P-Value \\
\hline $\begin{array}{l}\text { Kontrol } \\
\text { Sebelum }\end{array}$ & 21,56 & 41 & 4,97 & 0,78 & $-0,46$ & $-3,12$ & 40 & $0,003^{*}$ \\
Sesudah & 22,02 & 41 & 4,82 & 0,75 & $-0,76 ;-0,16$ & & & \\
\hline $\begin{array}{l}\text { Intervensi } \\
\text { Sebelum }\end{array}$ & 21,66 & 41 & 5,06 & 0,79 & $-3,15$ & $-15,55$ & 40 & $0,000^{*}$ \\
Sesudah & 24,80 & 41 & 4,94 & 0,77 & $-3,56 ;-2,74$ & & & \\
*: bermakna pada $\alpha=0,05$ & & & & & & &
\end{tabular}

*: bermakna pada $\alpha=0,05$

Peningkatan fungsi kognitif yang terjadi pada kelompok kontrol ini sesuai dengan pernyataan yang mengatakan bahwa latihan fisik dapat mengativasi sejumlah faktor yang pada akhirya bermuara pada neurogenesis dengan meningkatkan pengaktifan neuron-neuron yang diperantarai oleh BDNF (Brain Derived Neurotrophin Factor). BDNF merupakan neurotropin paling aktif yang membantu menstimulasi dan mengontrol proses neurogenesis. BDNF juga meningkatkan aktivasi neuron dan sinaps sehingga mempengaruhi sintesis dan fosforilasi Sinapsin I yang merupakan anggota fosfoprotein spesifik pada terminal saraf dan terlibat dalam pengeluaran neurotransmiter, pemanjangan akson dan pemeliharaan kontak sinaptik. Sehingga latihan fisik atau senam dapat membantu meningkatkan fungsi kognitif melalui peningkatan neurotransmiter. ${ }^{10}$

Pemberian aktifitas fisik dengan rutin dan teratur juga dilakukan pada kelompok kontrol dengan pemberian senam lansia setiap hari. Oleh karena

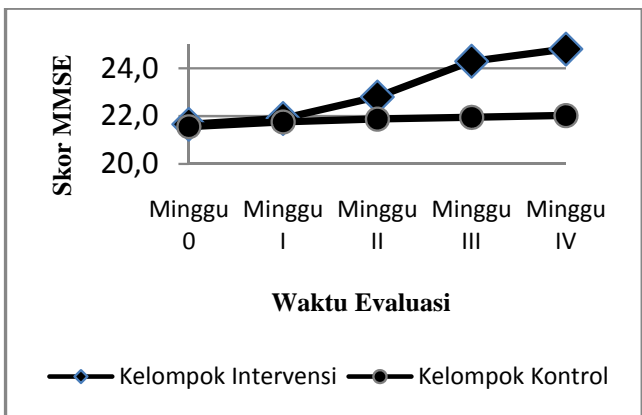

Gambar 5.1

Grafik Evaluasi Skor Fungsi Kognitif

Lansia dengan Demensia

Tahun 2012 itu terjadi peningkatan fungsi kognitif setelah dilakukan senam lansia. Peningkatan nilai fungsi kognitif pada kelompok kontrol ini disebabkan karena lansia dalam kegiatan sehari-harinya tidak hanya mendapatkan senam lansia tetapi lansia pada kelompok kontrol ini juga mendapatkan kegiatan lain seperti bimbingan ketrampilan, bimbingan psikologi, bimbingan rohani, bermain musik, menyanyi dan menari. Kegiatan-kegiatan tersebut juga dapat merangsang fungsi kognitif lansia.

Dari hasil analisis penelitian ini ditemukan bahwa peningkatan skor rata-rata fungsi kognitif kelompok intervensi lebih tinggi daripada kelompok kontrol. Latihan senam otak memberikan solusi yang sederhana untuk belajar bagi anak-anak dan orang dewasa setiap hari, latihan ini dapat mengatasi kesulitan-kesulitan seperti membaca menulis, menghitung berbahasa, musik dan olah raga. ${ }^{1}$ Penelitian lain juga menyebutkan bahwa senam otak dapat menurunkan tingkat depresi pada lansia dengan harga diri rendah. ${ }^{13}$

Perbedaan skor rata-rata fungsi kognitif pada lansia dengan demensia yang terjadi pada kelompok intervensi disebabkan karena manfaat Latihan senam otak dan art therapy lebih banyak pada merangsang aktivitas otak. Disamping itu pada setiap kegiatan latihan senam otak dan art therapy diawali dengan kuis atau pertanyaanpertanyaan yang terkait dengan orientasi baik waktu orang maupun tempat. Sedangkan manfaat senam lansia lebih kepada kekuatan otot, tulang dan sendi. Hal ini sesuai dengan penyataan bahwa senam lansia adalah serangkaian gerak dengan nada yang teratur dan terarah serta terencana yang diikuti oleh orang yang berusia di atas 60 tahun. Keuntungan dari senam lansia ini adalah melatih fisik dan kekuatan tulang yang melibatkan otototot besar dan latihan ditambah dengan beberapa bentuk permainan-permainan untuk meningkatkan 
koordinasi otak, keseimbangan dan kelenturan. Sehingga latihan fisik ini bertitik berat lebih pada keseimbangan, kekuatan otot dan kelenturan sendi lansia. $^{21}$

Tabel 3

Analisis Perbedaan Peningkatan Fungsi Kognitif Antara Kelompok Intervensi dengan Kelompok Kontrol pada Lansia dengan Demensia

Tahun 2012

\begin{tabular}{|c|c|c|c|c|c|c|c|c|c|}
\hline No & Kelompok & Mean & $\mathbf{N}$ & SD & SE & $\begin{array}{c}\text { MDiff } \\
(95 \% \text { CI })\end{array}$ & $\mathbf{t}$ & df & P-Value \\
\hline \multirow{3}{*}{1} & \multicolumn{9}{|c|}{ Post Intervensi } \\
\hline & Kontrol & 22,02 & 41 & 4,82 & 0,75 & $-2,78$ & $-2,58$ & 80 & $0,012^{*}$ \\
\hline & Intervensi & 24,80 & 41 & 4,94 & 0,77 & $(-4,93 ;-0,63)$ & & & \\
\hline \multirow{3}{*}{2} & \multicolumn{9}{|c|}{ Selisih Pre-post Intervensi } \\
\hline & Kontrol & 0,46 & 41 & 0,95 & 0,15 & $-2,68$ & $-10,69$ & 80 & $0,000 *$ \\
\hline & Intervensi & 3,15 & 41 & 1,30 & 0,20 & $(-3,18 ;-2,18)$ & & & \\
\hline
\end{tabular}

*: bermakna pada $\alpha=0,05$

Hasil analisis penelitian memaparkan bahwa pada kelompok kontrol rata-rata skor fungsi kognitif sebelum dan sesudah dilakukan senam lansia setiap hari selama 4 (empat) minggu memperlihatkan peningkatan fungsi kognitif yang bermakna yaitu sebesar $1,6 \%$, begitu juga pada kelompok intervensi sesudah diberikan latihan senam otak dan art therapy menunjukkan peningkatan yang bermakna dengan kenaikan ratarata skor gungsi kognitif sebesar $10,5 \%$. Hal ini menunjukkan bahwa pada kelompok intervensi peningkatan fungsi kognitif sebelum dan sesudah dilakukan latihan senam otak dan art therapy jauh melebihi peningkatan fungsi kognitif yang terjadi pada kelompok kontrol yang dibuktikan adanya selisih rata-rata skor fungsi kognitif antara kelompok kontrol dan kelompok intervensi yaitu sebesar 2,68. Data tersebut didukung oleh suatu pernyataan yang menyebutkan Cognitive Training seperti senam otak sangat bermanfaat mengatasi gangguan fungsi kognitif jika ditambah dengan tehnik stimulasi kognitif dan psikoterapi seperti terapi seni. $^{22}$

Tetapi walaupun kedua kelompok mengalami peningkatan yang bermakna dan kelompok intervensi lebih tinggi dibandingkan peningkatan rata-rata skor fungsi kognitif pada kelompok kontrol tetapi secara klinis peningkatan yang terjadi pada kelompok intervensi belum dapat meningkat ke level atau tingkatan berikutnya, terbukti kedua kelompok memiliki gambaran ratarata skor fungsi kognitifnya baik sebelum maupun sesudah diberikan intervensi masih berada pada tingkatan gangguan fungsi kognitif ringan. Hal ini disebabkan karena pemberian latihan senam otak dan art therapy dilakukan selama 4 (empat) minggu yang merupakan waktu awal dari adaptasi neuron saraf terhadap latihan fisik yang mencapai batas waktu akhir yaitu 6 (enam) minggu. ${ }^{19}$

\section{KETERBATASAN PENELITIAN}

Penetapan kriteria inklusi pada subyek penelitian demensia tidak dikategorikan ke dalam kategori jenis demensia yaitu demensia alzheimer, demensia vaskuler dan demensia campuran. Keterbatasan fisik lansia seperti mudah lelah dan tidak kuat berdiri lama menyebabkan lansia dalam melaksanakan latihan senam otak dalam posisi duduk walaupun pada gerakan-gerakan yang berdiri, sehingga ada beberapa lansia yang melaksanakan semua gerakan latihan senam otak dalam posisi duduk sehingga pelaksanaan latihan senam otak tidak maksimal. Begitu juga saat melakukan kegiatan art therapy atau menggambar peneliti yang menuliskan nama responden pada kertas gambar.

\section{SIMPULAN}

1. Karakteristik lansia dengan demensia baik pada kelompok kontrol di PSTW Yogyakarta Unit Abiyoso dan kelompok intervensi di Unit Budi Luhur sebagian besar berusia $70-$ 79 tahun dengan jenis kelamin sebagian besar adalah perempuan. Sebagian besar tingkat pendidikan lansia dengan demensia adalah tidak sekolah. Riwayat pekerjaan lansia dengan demensia sebagian besar adalah bekerja dengan jenis pekerjaan terbanyak adalah buruh dan pembantu rumah tangga. Sebagian besar lansia dengan demensia tidak mendapatkan dukungan keluarga dengan tidak pernah mendapatkan kunjungan keluarga. 
2. Tingkat fungsi kognitif pada lansia dengan demensia sebelum diberikan intervensi baik pada kelompok kontrol maupun intervensi termasuk ke dalam kategori gangguan kognitif ringan.

3. Terdapat peningkatan fungsi kognitif yang bermakna pada lansia dengan demensia sebelum dan sesudah dilakukan latihan senam otak dan art therapy selama 4 (empat) minggu pada kelompok intervensi dan pada kelompok kontrol sebelum dan sesudah dilakukan senam lansia.

4. Terdapat perbedaan peningkatan fungsi kognitif pada lansia dengan demensia sesudah dilakukan latihan senam otak dan art therapy pada kelompok intervensi dan sesudah senam lansia selama 4 (empat) minggu pada kelompok kontrol.

5. Peningkatan fungsi kognitif pada kelompok intervensi lebih tinggi dibandingkan dengan kelompok kontrol dengan selisih perbedaan sebesar 2,78 poin.

\section{KEPUSTAKAAN}

1. Anonymous. (2009). Learning Empowered by Movement; Brain Gym Exercise Wake Up Brain and Body. Biotech Business Week: 1683.

2. Badan Pusat Statistik. (2009). Statistik Penduduk Lansia 2009. Jakarta : Penerbit Badan Pusat Statistik.

3. BKKBN. (2012). Agar Tak Kesepian. Badan Kependudukan dan Keluarga Berencana Nasional Riau. Februari 6, 2012.

4. Crum, R.M., Anthony, J.C., Basset, S.S., \& Folstein, M.F. (1993). Population-Based Norms For Mini Mental State Examination by Age and Educational Level; Journal of American Medical Association, 29 (18). P. 2389.

5. Dennison, P.E., \& Dennison, G.E. (2006). Buku Panduan Lengkap Brain Gym ; Senam Otak. Ventura California : Edu - Kinesthetics, Inc.

6. Gelder, B. M. (2004). Physical Activity in Relation to Cognitive Decline in Elderlymen. The Journal of Neurology; 63: 2316 - 2321

7. Grayson, C. (2004). All about Alzheimer. Retrieved on October 2006

8. Hidayati, L.N. (2009). Hubungan Dukungan Sosial dengan Tingkat Depresi pada lansia di kelurahan Daleman Tulung Klaten.

9. Kim, S., K. (2010). Healthy Aging and Art Therapy. Disertasi. Lesley University. Proquest Data Base.

10. Kulak, W., \& Sobaniec, W. (2004). Molecular Mechanism of Brain Palsticity: Neurophysiologic and Neuroimaging Stroke in
Developing Patients. Annaks Academiae Medicae Bialostocensis 49 : 227 - 36.

11. Palestin, B., Nurrachmah, E., \& Ariawan, I. (2006). Pengaruh Umur, Depresi dan Demensia terhadap disabilitas Fungsional lansia di PSTW Abiyoso dan PSTW Budi Dharma Provinsi D.I Yogyakarta (Adaptasi Model Neuman), Fakultas Ilmu Keperawatan Universitas Indonesia. Tesis tidak dipublikasikan.

12. Peisah, C., Lawrence, G., \& Reutens, S. (2011). Case Report : Creative Solution for severe dementia with BPSD: a case of Art Therapy used in a patient and residential care setting. School of Psychiatriy, University of New South Wales, Sydney, Australia.

13. Prasetya, A.S., Achiryani, S.H., \& Susanti, H. (2010). Pengaruh Terapi Kognitif dan Senam Latih Otak Terhadap tingkat Depresi dengan Harga Diri Rendah pada Klien Lansia di Panti Tresna Wreda Bakti Yuswa Natar Lampung. Fakultas Ilmu Keperawatan Universitas Indonesia. Tesis tidak dipublikasikan

14. Putranto, P.,L., Bahtera, T., \& Rahmawati, D. (2009). Pengaruh Senam Otak Terhadap Memori Jangka Pendek pada Anak dari Keluarga Status Ekonomi Rendah. Ilmu Kesehatan Anak Universitas Diponegoro Semarang.

15. Rohana. (2010). Pengaruh senam vitalisasi otak terhadap fungsi kognitif pada lansia di Balai Perlindungan Sosial (BPS) Dinas Sosial Propinsi Banten.

16. Rustika \& Riyadina, W. (2000). Profil Penduduk Lanjut Usia di Indonesia. Jakarta

17. Sensus Penduduk, (2010). Statistik Penduduk Lanjut Usia Indonesia 2010 ; Hasil Sensus Penduduk 2010. Katalog BPS 4104061 Jakarta : Badan Pusat Statistik

18. Sensus Penduduk, (2010). Statistik Penduduk Lanjut Usia Provinsi DI Yogyakarta 2010 ; Hasil Sensus Penduduk 2010. Katalog BPS 4104001.34. Jakarta : Badan Pusat Statistik

19. Suhartono. (2005). Faktor-faktor Keseimbangan Pada Manusia dan Respon Umpan Balik Sensori Integrasi. Jakarta : Unit Press.

20. Tampubolon, A. (2008). Hubungan antara terjadinya infark pada lokasi tertentu di otak dengan timbulnya Demensia pasca stroke di RS Dr. Kariadi Semarang.

21. Tilarso, H. (1988). Latihan Fisik dan Usia Tua; Majalah Cermin Dunia Kedokteran No. 48. Jakarta.

22. Tsolaki, et al. (2009). Effectiveness of Non Pharmacological Approaches in Patients with Mild Cognitive Impairment. Original Paper Neurodegenerative Dis ;8; 138 - 145,. Karger AG, Basel. Proquest Data Base. 